\title{
An Indirect Method to Estimate Total Fertility Rate on the Basis of the Moments of Age Distribution of Women in Reproductive age
}

\author{
Brijesh P. Singh ${ }^{1}$, Sandeep Singh ${ }^{1} \&$ Aalok Ranjan Chaurasia ${ }^{2}$ \\ ${ }^{1}$ Department of Statistics, Institute of Science, Banaras Hindu University, Varanasi \\ ${ }^{2}$ MLC Foundation, Bhopal
}

\begin{abstract}
Total fertility rate (TFR) is the universally used indicator to measure and monitor fertility transition and population stabilization. Calculation of TFR requires data on births by age of woman. In the absence of these data, several indirect methods have been proposed to estimate TFR but their application is limited to specific period and place. This paper deduces a simple regression method for estimating TFR based on the current age distribution of women in reproductive age. The method can be used to estimate TFR at local level and for different sub-groups of the population.
\end{abstract}

Keywords: Total fertility rate; regression; moments; coefficient of variation; stability of model.

\section{Introduction}

Fertility is the primary engine of global population change (Gerland et al. 2014). Reduction in fertility is argued to be essential for sustainable development including woman education, child and maternal mortality, gender equality, and reproductive health (Abel et al. 2016). Total fertility rate (TFR) is a completed measure of fertility that is commonly used in demographic and development research. Direct estimation of TFR requires full birth history data (FBH) of women in reproductive age (15-49 years). These data are generally not available at the local level. To overcome this problem, different indirect methods of estimating TFR have been suggested. These include Brass P/F Ratio method (Brass 1975), Own Children method (Cho et al. 1986), and several regression methods (Bogue and Palmore 1964; Palmore 1978; Gunasekaran and Palmore 1984; and Rele 1967 and 1987; Pacheco and Engracia 1985; Rao 1987; Hanenberg 1983). Coale and Demeny (1967) developed a formula (TFR $=P_{3}{ }^{2} / P_{2}$ ) to estimate TFR, where $P_{2}$ and $P_{3}$ are mean number of births to women aged 20-24 and 25-29 years. This method has been modified by Gupta et al. (2014). Mauldin and Ross (1991) and Jain (1997) have used CPR to predict TFR. Singh et al. (2012) modified this method by taking the combination of CPR and sterility as predictor variables. Yadava and Kumar (2002) used proportion of women having open birth interval more than five years for prediction of TFR but this predictor has an error due to recall lapse and digit preference, therefore keeping this error into mind Singh et al. (2020) used the proportion of women having birth in the last five years prior to the date of survey as the predictor variable, as in count variable the chance of such type of error is lesser than the time variable (open birth interval more than five years) as taken by Yadava and Kumar (2002). Tiwari et al. (2020) used counterparts of the predictor variable taken by Singh et al. (2020) to estimate TFR. Singh et al. (2017) have suggested that IMR does not Granger Cause TFR whereas TFR Granger Cause IMR which means TFR can be predicted on the basis of IMR but IMR cannot be predicted on the basis of TFR. However, nearly all these methods are based on variables (mean age at marriage, percent of woman ever married, etc.) that are usually not available from census or survey data so that they are typically limited to areas, time periods, and populations with sufficiently detailed data. In addition, the relationship between 
fertility and social indices can differ over time and over populations, making indirect methods error prone when applied outside the context from which the regression coefficients are derived (Tuchfeld et al. 1974, Hauer et al. 2013, Schmertmann and Hauer 2019).

Palmore (1978) has suggested a method which is a modification of a technique introduced by Bogue and Palmore in 1964. Like Rele's method (1967), this method also postulates a linear relationship between the child woman ratio, a measure of mortality and TFR. However, unlike Rele's method, Palmore (1978) method is derived empirically using census and vital registration data from different countries. This method requires more data than Rele's method, but the data required are usually available from census or surveys. Moreover, instead of using the expectation of life at birth, Palmore (1978) uses IMR as the measure of mortality. It has been observed that Rele's method tends to under-estimate fertility whereas Palmore (1978) method tends to over-estimate TFR particularly when IMR decreases rapidly. Gunasekaran and Palmore (1984) developed a regression method to estimate gross reproduction rate (GRR) and then TFR by multiplying GRR by 2.05. They used moments of the entire woman age distribution instead of the child woman ratio. Also Smith (1992) and Zhang (2006) observed TFR and the general fertility rate are directly proportional to the crude birth rate, however, Preston and Coale (1982) developed a method for calculating the TFR based on net population reproductivity.

In this paper, we develop a regression method similar to Gunasekaran and Palmore (1984). The advantage of the method being proposed here is that the data pertaining to the age distribution of currently married reproductive age women can be culled out from the records maintained by the grassroots level health and family welfare services providers. As such, the method can be used for estimating TFR even at the grassroots level which, then, can become the basis for planning for the delivery of family welfare services and monitoring fertility transition at the grassroots level. This is important as reliable demographic data for small domains are essential for meaningful local level population planning. Estimation of demographic indicators at the grassroots level is based on the civil registration data. Although, registration of births in India is compulsory under the Birth and Death Registration Act of 1969, yet registration under the civil registration system in India grossly incomplete to calculate fertility indicators including TFR. Annual estimates of TFR in India are available through the Sample Registration System (SRS) but the system provides estimates up to state level only and that too for major states. The only source of data to estimate TFR at the district level is the summary birth history (SBH) data available through decennial population census. Using these data, estimates of TFR have been calculated at the district level (Bhat, 1996; Drěze and Murthi, 2001; Satyanarayana and Kumar, 2012; Guilmoto and Rajan, 2013; Ponnapalli and Soren, 2018). These estimates, however, are available at an interval of 10 years only (Natarajan and Singh 1988; Natarajan and Puri 1988; RGI, 1997, 2011).

\section{Development of the Model}

The model proposed for estimating TFR is based on establishing an empirical relationship between TFR and the age distribution of currently married women in the reproductive age group. The age distribution of currently married reproductive age women can be characterised in terms of the first four moments of the age distribution. In the present paper, we have attempted to establish empirical relationship between TFR and coefficient of variation $(C V)$, involving first and second moments; skewness $(S k)$, involving third and second moments; and kurtosis $(K u)$, involving fourth and second moments. Using these three indicators the following seven models depicting the relationship between TFR and the age distribution of currently married reproductive age women can be conceptualized: 


$\begin{array}{llrl} & \text { Model 1 } & \Rightarrow T F R=f(C V, S k, K u) \\ \text { Model 2 } & \Rightarrow T F R=f(C V, S k) & \text { Model 3 } & \Rightarrow T F R=f(C V, K u) \\ \text { Model 4 } & \Rightarrow T F R=f(S k, K u) & \text { Model 5 } & \Rightarrow T F R=f(C V) \\ \text { Model 6 } & \Rightarrow T F R=f(S k) & \text { Model 7 } & \Rightarrow T F R=f(K u)\end{array}$

In order to test the cross-validity predictive power of these models, we have used the method proposed by Herzberg (1969). The cross-validity prediction power of the model is calculated as

$\rho_{v}^{2}=1-\frac{\left(n^{2}-1\right)(n-2)\left(1-c^{2}\right)}{n(n-p-1)(n-p-2)}$

Where $n$ is the number of observations, $p$ is the number of explanatory or independent variables in the model and $c$ is the correlation coefficient between predicted and observed value of the dependent variable or TFR. Moreover, standard adjustment has been made in the coefficient of determination to compensate for the subjective effects of further sampling. We have also estimated shrinkage which is the reduction in the effects of sampling variation. It is well known in the regression analysis that a fitted relationship performs less well on a new data set than on the data set that is used for fitting (Everitt, 2002) so that the value of the coefficient of determination, particularly, 'shrinks'. Shrinkage is separate from the standard adjustment made in the coefficient of determination. The shrinkage of the model is estimated by the following formula:

Shrinkage $=\left|\rho_{v}^{2}-r^{2}\right|$

where $r^{2}$ is the coefficient of determination. Finally, we have also calculated the stability of the model which is equal to (1-Shrinkage) which implies that the lower the shrinkage the more stable the model.

\section{Source of Data}

In order to examine the empirical relationship between TFR and the age distribution of currently married reproductive age women, we have used data available from the fourth round of the National Family Health Survey (NFHS) which was conducted during 2015-16. The National Family Health Survey Programme was launched by the Government of India, Ministry of Health and Family Welfare in the 1990s to generate population-based data to monitor and evaluate the family planning and reproductive and child health programmes at national and state levels.

Table 1. Statistical Moments of Age Distribution of Women in India and Major States NFHS-4

\begin{tabular}{|c|c|c|c|c|c|}
\hline State & $\begin{array}{c}\text { Mean } \\
\left(\mu_{1}^{\prime}\right)\end{array}$ & $\mu_{2}$ & $\mu_{3}$ & $\mu_{4}$ & $\mathbf{N}$ \\
\hline Andhra Pradesh & 31.29 & 94.09 & 118.65 & 16643.50 & 10428 \\
\hline Bihar & 28.69 & 94.67 & 350.04 & 18194.80 & 45812 \\
\hline Chhattisgarh & 29.60 & 97.81 & 319.23 & 18751.73 & 25172 \\
\hline Gujarat & 30.42 & 95.06 & 157.57 & 16898.96 & 22932 \\
\hline Haryana & 29.76 & 90.82 & 285.62 & 16496.87 & 21654 \\
\hline Jharkhand & 29.14 & 92.74 & 312.57 & 17286.27 & 29046 \\
\hline Karnataka & 30.63 & 92.16 & 150.41 & 16222.52 & 26291 \\
\hline Kerala & 32.16 & 99.20 & -19.76 & 17910.54 & 11033 \\
\hline
\end{tabular}




\begin{tabular}{|c|c|c|c|c|c|}
\hline Madhya Pradesh & 29.61 & 97.22 & 297.16 & 18241.69 & 62803 \\
\hline Maharashtra & 30.34 & 97.22 & 182.13 & 17769.10 & 29460 \\
\hline Odisha & 30.30 & 97.02 & 210.25 & 17791.26 & 33721 \\
\hline Punjab & 30.88 & 91.39 & 139.80 & 16037.36 & 19484 \\
\hline Rajasthan & 29.10 & 93.51 & 325.52 & 17312.95 & 41965 \\
\hline Tamil Nadu & 31.40 & 95.84 & 75.07 & 17177.99 & 28820 \\
\hline Telangana & 30.55 & 91.58 & 219.12 & 16188.44 & 7567 \\
\hline Uttarakhand & 29.55 & 96.04 & 282.36 & 17893.94 & 17300 \\
\hline Uttar Pradesh & 28.60 & 96.63 & 389.44 & 18580.92 & 97661 \\
\hline West Bengal & 30.55 & 91.58 & 219.12 & 16188.44 & 17668 \\
\hline INDIA & $\mathbf{2 9 . 8 3}$ & $\mathbf{9 5 . 2 6}$ & $\mathbf{2 5 1 . 0 2}$ & $\mathbf{1 7 5 1 2 . 8 4}$ & $\mathbf{6 9 9 6 8 6}$ \\
\hline
\end{tabular}

The NFHS has been expanded to generate district level data in the fourth round. The first four moments of the age distribution of currently married reproductive age women in India and in its different states are presented in table 1. It is evident from the table that the age distribution of currently married reproductive age women varies widely across states. Notably, there is only one state, Kerala, where the third moment of the age distribution of reproductive age women is negative in rest of the states, it is positive. On the other hand, the age curve is platykurtic in all states as well as in the country. Table 1 reveals that the statistical moments of the age distribution of women in reproductive age in India and some major states for NFHS-4 data. In southern states the mean age is higher than the northern and other states.

Table 2. Regression Models, $r^{2}$ (Coefficient of Determination), Adjusted $r^{2}$ and Standard Error

\begin{tabular}{|c|c|c|c|c|}
\hline Model & Mathematical form & $r^{2}$ & $\begin{array}{c}\text { Adjusted } \\
r^{2}\end{array}$ & $\begin{array}{c}\text { Standard } \\
\text { error }\end{array}$ \\
\hline 1 & TFR $=44.708\left(C V^{* * *}\right)-3.699\left(S k^{*}\right)+7.724\left(K u^{* *}\right)-3.149$ & 0.900 & 0.870 & 0.181 \\
\hline 2 & TFR $=31.885\left(C V^{* * *}\right)+0.759(S k)-8.352$ & 0.797 & 0.760 & 0.246 \\
\hline 3 & TFR $=28.937\left(C V^{* *}\right)+2.768(K u)-4.247$ & 0.854 & 0.817 & 0.215 \\
\hline 4 & TFR $=2.191(S k)+2.402(K u)+4.181$ & 0.653 & 0.590 & 0.322 \\
\hline 5 & TFR $=38.717\left(C V^{* * * *}\right)-10.381$ & 0.787 & 0.769 & 0.241 \\
\hline 6 & TFR $=3.624\left(S k^{* * * *}\right)+1.350$ & 0.640 & 0.610 & 0.313 \\
\hline 7 & TFR $=6.559\left(K u^{* * *}\right)+9.157$ & 0.609 & 0.576 & 0.327 \\
\hline
\end{tabular}

$*=\mathrm{p}<0.05, * *=\mathrm{p}<0.01, * * *=\mathrm{p}<0.001$

Coefficient of variation $(C V)=\frac{\mu_{1}^{\prime}}{\mu_{2}}$, Skewness $(S k)=\frac{\mu_{3}}{\mu_{2}^{3 / 2}}$ and Kurtosis $(K u)=\frac{\mu_{4}}{\mu_{2}^{2}}-3$

Table 3. Correlation between Observed and Predicted Value of TFR $\left(c^{2}\right)$ RMSE, $\rho_{v}^{2}$ and Stability of $r^{2}$

\begin{tabular}{|c|c|c|c|c|c|}
\hline Model & $c^{2}$ & RMSE & $\rho_{v}^{2}$ & Shrinkage of $r^{2}$ & Stability of $r^{2}$ \\
\hline 1 & 0.928 & 0.170 & 0.788 & 0.112 & 0.888 \\
\hline 2 & 0.868 & 0.222 & 0.708 & 0.089 & 0.911 \\
\hline 3 & 0.900 & 0.197 & 0.775 & 0.079 & 0.921 \\
\hline 4 & 0.796 & 0.268 & 0.566 & 0.087 & 0.913 \\
\hline 5 & 0.881 & 0.228 & 0.733 & 0.057 & 0.943 \\
\hline 6 & 0.783 & 0.306 & 0.541 & 0.099 & 0.901 \\
\hline 7 & 0.770 & 0.277 & 0.518 & 0.092 & 0.908 \\
\hline
\end{tabular}




\section{Results and Discussion}

Table 2 shows the relationship between TFR and different indicators characterizing the age distribution of currently married reproductive age women. In all models, the regression coefficients are statistically significant but the coefficient of determination is the highest in Model 1. The standard error of $r^{2}$ is also the lowest in Model 1. On the other hand, Table 3 presents the correlation between observed and predicted values of TFR $\left(c^{2}\right)$, root mean square error (RMSE), Cross-validity prediction power $\rho_{v}^{2}$ and stability of $r^{2}$ for different

Table 4. Observed and Predicted TFR through Various Regression Models for Some Major States of India NFHS-4

\begin{tabular}{|c|c|c|c|c|c|c|c|c|c|c|c|c|c|c|c|}
\hline \multirow{3}{*}{ States } & \multirow{3}{*}{$\begin{array}{l}\text { Observ } \\
\text { ed TFR }\end{array}$} & \multicolumn{14}{|c|}{ Estimated TFR by } \\
\hline & & \multicolumn{2}{|c|}{ Model 1} & \multicolumn{2}{|c|}{ Model 2} & \multicolumn{2}{|c|}{ Model 3} & \multicolumn{2}{|c|}{ Model 4} & \multicolumn{2}{|c|}{ Model 5} & \multicolumn{2}{|c|}{ Model 6} & \multicolumn{2}{|c|}{ Model 7} \\
\hline & & $\begin{array}{c}\text { estima } \\
\text { te }\end{array}$ & \begin{tabular}{c|}
$\%$ \\
Diff.
\end{tabular} & $\begin{array}{c}\text { estima } \\
\text { te }\end{array}$ & $\begin{array}{c}\% \\
\text { Diff. }\end{array}$ & $\begin{array}{c}\text { estima } \\
\text { te }\end{array}$ & $\begin{array}{c}\% \\
\text { Diff. }\end{array}$ & $\begin{array}{c}\text { estima } \\
\text { te }\end{array}$ & \begin{tabular}{|c|}
$\%$ \\
Diff.
\end{tabular} & $\begin{array}{c}\text { estima } \\
\text { te }\end{array}$ & \begin{tabular}{|c|}
$\%$ \\
Diff.
\end{tabular} & $\begin{array}{c}\text { estima } \\
\text { te }\end{array}$ & $\begin{array}{c}\% \\
\text { Diff. }\end{array}$ & $\begin{array}{c}\text { estima } \\
\text { te }\end{array}$ & $\begin{array}{c}\% \\
\text { Diff. }\end{array}$ \\
\hline & 1.83 & 1.58 & 13.72 & 1.63 & 10.87 & 1.62 & 11.29 & 1.78 & 2.97 & 1.62 & 11.40 & 1.82 & 0.49 & 1.81 & 1.04 \\
\hline Bihar & & & 8.64 & 2.75 & 19.36 & 2.88 & 15.49 & 2.68 & 21.30 & 2.75 & 19.37 & 2.73 & 20.03 & 2.79 & 18.04 \\
\hline Chhattisgarh & 2.23 & 2.54 & 13.69 & 2.55 & 14.44 & 2.54 & 14.02 & 2.41 & -7.89 & 2.56 & 14.58 & 2.55 & 14.17 & 2.34 & -4.74 \\
\hline Gujarat & 203 & & 10.17 & 200 & 1.65 & 100 & 6.41 & 1.84 & 9.40 & 2.03 & 0.08 & 107 & 3.15 & 1.75 & 4.02 \\
\hline Haryana & 2.05 & 2.22 & -8.44 & 2.11 & -2.88 & 2.25 & -9.83 & 2.50 & 22.05 & 2.02 & 1.60 & 2.55 & 24.19 & 2.60 & ${ }^{-}-\overline{73}$ \\
\hline Jharkhand & & & -5.27 & 245 & 3.89 & 58 & -1.00 & 2.57 & -0.78 & 2.41 & 5.34 & 262 & -2.68 & 2.66 & -4.45 \\
\hline Karnataka & 1.80 & 1.82 & -0.85 & 1.77 & 1.65 & 1.81 & -0.29 & 1.94 & -7.52 & 1.75 & 2.58 & 1.97 & -9.23 & 2.01 & ${ }^{-}-{ }^{-}$ \\
\hline erala & & & -6.20 & 151 & 3.36 & & 714 & 130 & 6.49 & 1.61 & -3.19 & & 18.11 & 1.42 & 9.14 \\
\hline & 2.32 & 2.33 & -0.31 & 2.50 & -7.80 & 2.43 & -4.62 & 2.29 & 1.29 & 2.51 & -8.26 & 2.47 & -6.61 & 2.14 & 7.81 \\
\hline Maharashtra & & 2.03 & -8.38 & 2.15 & $\begin{array}{c}- \\
15.20\end{array}$ & 2.06 & -9.99 & 1.91 & -1.98 & 2.20 & $\begin{array}{c}- \\
17.72\end{array}$ & 2.04 & -9.01 & 1.81 & 3.16 \\
\hline Odisha & & & & & -6.35 & & -1.83 & & 2.60 & 2.21 & -7.57 & & -4.75 & & 8.46 \\
\hline Punjab & 1.62 & 1.76 & -8.53 & 1.64 & -1.27 & 1.72 & -6.30 & 1.94 & $\begin{array}{c}- \\
19.59\end{array}$ & 1.61 & 0.91 & 1.93 & 19.13 & 2.07 & $\begin{array}{c}- \\
27.98 \\
\end{array}$ \\
\hline Rajasthan & & 2.50 & -4.06 & 2.52 & -4.86 & 2.55 & -6.06 & 2.52 & -4.99 & 2.48 & -3.53 & 2.65 & $\begin{array}{c}- \\
10.61\end{array}$ & 2.47 & -2.78 \\
\hline Tamil Nadu & & & -3.89 & 65 & 2.95 & & 3.10 & 1.64 & 3.41 & 1.69 & 0.57 & 1.6 & 3.53 & 1.75 & -2.67 \\
\hline Telangana & 1.78 & 1.67 & 6.37 & 1.83 & -2.58 & 1.86 & -4.27 & 2.16 & 21.27 & 1.75 & 1.83 & 2.26 & $\begin{array}{c}- \\
26.74\end{array}$ & 2.14 & 20.16 \\
\hline Uttarakhand & & 2.38 & 15.02 & 2.45 & 18.36 & 2.42 & 16.70 & 2.29 & $\begin{array}{c}- \\
10.73\end{array}$ & 2.46 & 18.80 & 2.44 & $\begin{array}{c}- \\
17.74\end{array}$ & 2.20 & -6.50 \\
\hline Uttar Pradesh & & 2.90 & -5.82 & 2.92 & -6.51 & 2.90 & -5.95 & 2.65 & 3.16 & 2.93 & -6.80 & 2.84 & -3.50 & 2.53 & 7.58 \\
\hline West Bengal & 1.77 & 1.67 & 5.84 & 1.83 & -3.16 & 1.86 & -4.86 & 2.16 & 21.96 & 1.75 & 1.28 & 2.26 & $\begin{array}{c}- \\
27.46\end{array}$ & 2.14 & 20.84 \\
\hline III & 2.18 & 2.22 & -1.63 & 2.29 & -4.83 & 2.26 & -3.63 & 2.20 & -1.03 & 2.29 & -4.90 & 2.33 & $-6.81 \mid$ & 2.14 & 1.89 \\
\hline
\end{tabular}

Model 1 and also the root mean square error (RMSE) is the lowest for model 1. Cross validity prediction power $\rho_{v}^{2}$ also suggests that Model 1 is the most powerful among the seven models. However, the shrinkage is the lowest in Model 5 whereas its stability is high in all the seven models. Model 1 shows highest $r^{2}$ and $\rho_{v}^{2}$ but the lowest RMSE and shrinkage of the model is high so that its stability is quite low. Ranking all the 
seven models in terms of five parameters $r^{2}$, RMSE, $\rho_{v}^{2}$, shrinkage of $r^{2}$ and stability of $r^{2}$ the mean rank score has been found to be the lowest in case of Model 5 which means that Model 5 best estimates TFR among the seven models. A comparison of the observed and estimated values of TFR based on different models is given in Table 4. The predicted value of TFR is close to the observed values in case of all models. The percent difference between observed and estimated TFR is also shown in the table. For model 1, 2, 3, 4, 6 and 7, more than half of the states show over estimation in TFR and for Model 5, only 8 states show over estimation. An interesting result from the Table 4 is that all models provide under-estimated TFR for Bihar and over-estimated TFR for Uttarakhand. The possible reason may be the variability in the age distribution of currently married reproductive age women in the two states.

\section{Validation of Model 5}

We have used Model 5 to estimate TFR at district level on the basis of the data available from NFHS-4. Moreover, we have also compared TFR estimates for the districts of Uttar Pradesh obtained from Model 5 with the estimates obtained by Jayachandran and Ram (2019) using the tfr2 SATA module (Schoumaker, 2013) using the data from NFHS-4 and shown in Table 5. It is interesting that there is a good agreement in the results that in 27 districts the difference is less than 10 percent in TFRs. 19 districts have differences in TFRs between 10-20 percent and 12 districts between 20-30 percent. Rest in 11 districts, the TFR differs more than 30 percent. Maximum differences observed in Lucknow, Kanpur Nagar, Rai Bareli, Pratapgarh, Bahraich, Shrawasti and Mahoba. In the appendix estimate of TFR and its standard error (SE) for all districts of India is provided. These estimates may be helpful for programme makers for future planning of intervention programme.

\section{Conclusion}

The simple method proposed in this paper, involving first and second moments of the age distribution of currently married reproductive age women, provides fairly reliable estimate of TFR. Data pertaining to the age of currently married reproductive age women is regular collected and maintained at the grassroots level by the health care services providers. This means that the paper proposed can be used to estimate TFR at the grass roots level. This will help measuring and monitoring fertility transition at the local level, the interface with the people.

Table 5. Comparison of TFR in Uttar Pradesh

\begin{tabular}{|c|c|c|c|}
\hline \multirow{2}{*}{ Districts } & \multicolumn{2}{|c|}{ Estimated TFR } & Absolute \\
\cline { 2 - 3 } & $\begin{array}{c}\text { Jaychandran } \\
\text { \& Ram (2019) }\end{array}$ & $\begin{array}{c}\text { Model } \\
\text { 5 }\end{array}$ & $\begin{array}{c}\text { Percent } \\
\text { difference }\end{array}$ \\
\hline Kanpur Dehat & 2.54 & 2.53 & 0.29 \\
\hline Chitrakoot & 3.36 & 3.38 & 0.61 \\
\hline Bulandshahar & 2.92 & 2.94 & 0.71 \\
\hline Etah & 3.02 & 2.99 & 0.94 \\
\hline Saharanpur & 2.72 & 2.69 & 1.13 \\
\hline Aligarh & 2.85 & 2.90 & 1.83 \\
\hline Kaushambi & 3.27 & 3.37 & 3.21 \\
\hline Basti & 3.01 & 3.12 & 3.59 \\
\hline Kannauj & 3.06 & 2.94 & 3.96 \\
\hline Lalitpur & 2.31 & 2.40 & 4.08 \\
\hline Agra & 2.80 & 2.92 & 4.34 \\
\hline Sant Ravidas & 3.00 & 2.87 & 4.38 \\
\hline
\end{tabular}




\begin{tabular}{|c|c|c|c|}
\hline Nagar & & & \\
\hline Chandauli & 2.75 & 2.89 & 5.11 \\
\hline Barabanki & 2.60 & 2.76 & 6.17 \\
\hline $\begin{array}{c}\text { Sant Kabir } \\
\text { Nagar }\end{array}$ & 3.05 & 3.24 & 6.33 \\
\hline Mirzapur & 2.91 & 2.72 & 6.69 \\
\hline Hardoi & 3.03 & 2.81 & 7.39 \\
\hline Pilibhit & 2.73 & 2.95 & 8.15 \\
\hline Auraiya & 2.60 & 2.38 & 8.28 \\
\hline Banda & 2.67 & 2.89 & 8.39 \\
\hline Moradabad & 2.95 & 3.20 & 8.47 \\
\hline Rampur & 2.94 & 3.19 & 8.55 \\
\hline Juanpur & 2.72 & 2.95 & 8.61 \\
\hline Ghaziabad & 2.42 & 2.64 & 8.97 \\
\hline $\begin{array}{l}\text { Siddhartha } \\
\text { Nagar }\end{array}$ & 3.41 & 3.08 & 9.59 \\
\hline Sonbhadra & 2.83 & 2.55 & 9.88 \\
\hline JP Nagar & 2.95 & 3.24 & 9.96 \\
\hline Farrukhabad & 3.24 & 2.90 & 10.64 \\
\hline Gonda & 3.31 & 2.96 & 10.71 \\
\hline Muzaffarnagar & 3.10 & 2.74 & 11.56 \\
\hline Mathura & 2.88 & 3.22 & 11.66 \\
\hline Kushinagar & 3.00 & 3.37 & 12.36 \\
\hline Allahabad & 2.46 & 2.78 & 12.85 \\
\hline Bijnor & 2.74 & 3.09 & 12.92 \\
\hline Ballia & 2.84 & 3.23 & 13.62 \\
\hline Shahjahanpur & 3.48 & 2.99 & 14.02 \\
\hline Etawah & 2.51 & 2.87 & 14.46 \\
\hline Unnao & 2.74 & 3.14 & 14.77 \\
\hline Ghazipur & 2.80 & 3.22 & 14.96 \\
\hline Budaun & 3.73 & 3.12 & 16.32 \\
\hline Mahrajganj & 2.82 & 3.29 & 16.61 \\
\hline Firozabad & 2.78 & 3.26 & 17.10 \\
\hline Varanasi & 2.22 & 2.60 & 17.29 \\
\hline Meerut & 2.27 & 2.72 & 19.86 \\
\hline Mainpuri & 2.69 & 3.23 & 19.92 \\
\hline Balrampur & 3.38 & 2.71 & 19.94 \\
\hline Sitapur & 3.32 & 2.62 & 21.02 \\
\hline $\begin{array}{c}\text { Gautam } \\
\text { Buddha Nagar }\end{array}$ & 2.61 & 2.06 & 21.21 \\
\hline Kheri & 3.38 & 2.62 & 22.44 \\
\hline Faizabad & 2.63 & 3.25 & 23.74 \\
\hline $\mathrm{Mau}$ & 2.66 & 3.30 & 24.20 \\
\hline Deoria & 2.43 & 3.02 & 24.34 \\
\hline Fatehpur & 2.32 & 2.90 & 24.95 \\
\hline Sultanpur & 2.74 & 3.42 & 24.97 \\
\hline Gorakhpur & 2.38 & 2.98 & 25.04 \\
\hline Hamirpur & 2.34 & 2.93 & 25.25 \\
\hline Jalaun & 2.00 & 2.56 & 27.80 \\
\hline $\begin{array}{c}\text { Ambedkar } \\
\text { Nagar }\end{array}$ & 2.36 & 3.07 & 29.99 \\
\hline Azamgarh & 2.45 & 3.19 & 30.04 \\
\hline Jhansi & 2.05 & 2.67 & 30.39 \\
\hline Baghpat & 2.24 & 2.92 & 30.41 \\
\hline Bareilly & 2.52 & 3.34 & 32.68 \\
\hline Pratapgarh & 2.30 & 3.15 & 37.10 \\
\hline Rae Bareli & 2.48 & 3.43 & 38.19 \\
\hline Kanpur Nagar & 1.64 & 2.32 & 41.73 \\
\hline Mahoba & 2.43 & 3.51 & 44.27 \\
\hline Bahraich & 4.22 & 2.22 & 47.51 \\
\hline Lucknow & 1.58 & 2.33 & 47.69 \\
\hline
\end{tabular}




\begin{tabular}{|c|c|c|c|}
\hline Shrawasti & 4.40 & 2.27 & 48.32 \\
\hline $\begin{array}{c}\text { Uttar } \\
\text { Pradesh }\end{array}$ & $\mathbf{3 . 3 0}$ & $\mathbf{2 . 9 3}$ & $\mathbf{1 1 . 2 1}$ \\
\hline
\end{tabular}

\section{References}

[1] Abel, G. J., Barakat, B., Samir, K. C., \& Lutz, W. (2016). Meeting the Sustainable Development Goals leads to lower world population growth. Proceedings of the National Academy of Sciences, 113(50), 14294-14299.

[2] Bhat P. N.M., (1996). Contours of fertility decline in India: A district level study based on the1991 Census," in K Srinivasan (ed.), Population Policy and Reproductive Health, New Delhi: Hindustan Publishing Corporation.

[3] Bogue, D. J., \& Palmore, J. A. (1964). Some empirical and analytic relations among demographic fertility measures, with regression models for fertility estimation. Demography, 1(1), 316-338.

[4] Brass, W. (1968). Methods of analysis and estimation. The Demography of Tropical Africa. Edited by W. Brass et al., Princeton University Press, Princeton.

[5] Cho, L. J., Retherford, R. D., \& Choe, M. K. (1986). The own-children method of fertility estimation. Honolulu, HI: Population Institute.

[6] Coale, A., \& Demeny, P. (1967). Methods of estimating basic demographic measures from incomplete data, manuals on methods of estimating population, Manual 4, New York: United Nations, Department of Economics and Social Affairs.

[7] Drěze, Jean and Murthi, Mamta, (2001). Fertility, Education, and Development: Evidence from India, Population and Development Review, 27(1): 33-63.

[8] Everitt, B.S. (2002). Cambridge Dictionary of Statistics, $2^{\text {nd }}$ Edition. OUP.

[9] Gerland, P., Raftery, A. E., Sev`c'ikov'a, H., Li, N., Gu, D., Spoorenberg, T., Alkema, L., Fosdick, B. K., Chunn, J. \& Lalic, N. (2014). World population stabilization unlikely this century. Science, 346(6206), 234-237.

[10] Guilmoto, Christophe Z and Rajan, S. Irudaya, (2013) Fertility at the district level in India, Economic and Political Weekly, 48(23): 59-70.

[11] Gunasekaran, S., \& Palmore,J. A. (1984). Regression estimates of the gross reproduction rate using moments of the female age distribution. Asian and Pacific Census Forum, 10(4), 5-10.

[12] Gupta, K., Singh, Brijesh P., \& Singh, K. K. (2014). Estimation of total fertility rates in India using indirect techniques. Journal of National Academy of Mathematics, 28, 21-28.

[13] Hanenberg, R. (1983). Estimates of the total fertility rate based on the child-woman ratio. Asian and Pacific Census Forum. 10(2), 5-11.

[14] Hauer, M., Baker, J. \& Brown, W. (2013). Indirect estimates of total fertility rate using child woman ratio: A comparison with the Bogue-Palmore method. PloSOne8(6), e67226.

[15] Herzberg, P. A. (1969). The parameters of cross validation. Psychometrika Monograph Supplement, 16. 34(2), 1-70.

[16] International Institute for Population Sciences (IIPS) and ICF, (2017). National Family Health Survey (NFHS-4), 2015-16: India. Mumbai: IIPS.

[17] Jain, A. (1997). Consistency between contraceptive use and fertility in India. Demography India, 26(1),19-36.

[18] Jayachandran A. A. \& F. Ram (2019). Estimation of District Level TFR of Eight EAG States and Assam from NFHS-4, 2015-16. Demography India Vol. 48, No. 1, pp. 63-73.

[19] Mauldin, W. P., \& Ross J. A. (1991). Family planning programmes: Efforts and Results, 19821989. Studies in family planning, 22(6), 350-367.

[20] Natarajan, K. S., \& Singh, P. (1988). Fertility in India: An analysis of 1981 census data. Occasional Paper No. 13 of 1988. New Delhi: Demography Division, Office of the Registrar General, India.

[21] Natarajan, K. S., \& Puri, R. K. (1988). Child mortality estimates of India. Occasional Papers No.5 of 1988. New Delhi: Demography Division, Office of the Registrar General, India. 
[22] Office of Registrar General, India, (2011). Annual Health Survey (AHS) in 8 EAG States and Assam-Release of AHS Bulletin: 2010-11, Press Release, Ministry of Home Affairs, New Delhi. www.censusindia.gov.in/vital_statistics/AHSBulletins/files/AHSpr.pdf.

[23] Pacheco, Antonio R., \& Luisa, T. Engracia. (1985). Indirect estimates of fertility for small geographic areas in the Philippines. United Nations Economic and Social Commission for Asia and the Pacific, Bangkok. Asian Population Studies Series. No. 62 - D. New York: United Nations.

[24] Palmore, J. A. (1978). Regression estimates of changes in fertility 1955-60 to 1965-75, for most major nations and territories. Papers of the East-West Population Institute. No.58. Honolulu: EastWest Center.

[25] Ponnapalli, K.M. and Soren, R.K., (2018). Indirect Estimation of Selected Measures of Fertility and Marital Fertility from Information on CWR (0-9): An Application to India/States/Districts", Momona Ethiopian Journal of Science, 10 (1): 89 - 108.

[26] Preston, S.H. \& Coale, A.J. (1982). Age structure, growth, attrition and accession: A new synthesis. Population Index, 48(2), 217-259.

[27] Rao, N. Rama, Rele, J. R., \& Palmore, J. A. (1987). Regression estimates of fertility for India, 1971 and 1981. Occasional Paper No.3 of 1987. Delhi: Office of the Registrar General and Census Commissioner.

[28] Registrar General of India, 1997, District level estimates of fertility and child mortality for1991 and their interrelations with other variables, Occasional paper No 1 of 1997, New Delhi: Controller of Publications.

[29] Rele, J. R. (1967). Fertility analysis through extension of stable population concepts. Berkeley: Institute of International Studies, University of California. (Ph.D. dissertation).

[30] Rele, J. R. (1987). Fertility levels and trends in India, 1951-1981. Population and Development Review, 13(3), 513-530.

[31] Satyanarayana, K.M. and Kumar, Sanjay, (2012). District-level estimates of fertility and implied sex ratio at birth in India, Economic and Political Weekly, 47(33): 66-72.

[32] Schmertmann, C. P. \& Hauer, M. E. (2019). Bayesian estimation of total fertility from a population's age-sex structure. Statistical Modelling, 19(3), 225-247.

[33] Schoumaker, Bruno, (2013). A State module for computing fertility rates and TFRs from birth histories: tfr2, Demographic Research, 28(38): 1093-1144.

[34] Singh, Brijesh P., Dixit, S., \& Singh, S. (2017). Does infant mortality regulate fertility behaviour of women in Uttar Pradesh? A causality test analysis. Demography India, 46(1), 38-47.

[35] Singh, Brijesh P., Singh, N., \&Singh, S. (2020). Estimation of total fertility rate: an indirect approach using auxiliary information. Journal of the Social Sciences, 48(3), 789-798.

[36] Singh, K. K., Singh, Brijesh P., \&Gupta, K. (2012). Estimation of total fertility rate and birth averted due to contraception: regression approach. International Journal of Statistics and Applications, 2(5), 47-55.

[37] Smith, D.P. (1992). Formal Demography: Springer US.

[38] Tiwari, A. K., Singh, Brijesh. P., \& Patel, V. (2020). Retrospective study of investigation of possible predictors for total fertility rate in India. Journal of Scientific Research and Reports, 26(9), 111-119.

[39] Tuchfeld, B. S., Guess, L. L. \& Hastings, D. W. (1974). The Bogue-Palmore technique for estimating direct fertility measures from indirect indicators as applied to Tennesseecounties, 1960 and 1970. Demography, 11(2), 195-205.

[40] Yadava, R. C., \& Kumar, A. (2002). On an indirect estimation of total fertility rate from open birth interval. Demography India, 31(2), 211-222.

[41] Zhang, Q. (2006). Estimation and analysis on total fertility rate (in Chinese). Chinese Journal of Population Science, (4), 35-42. 


\section{Appendix}

Table 6. Estimated TFR for all districts of India and Standard Error (SE) using Model 5

\begin{tabular}{|c|c|c|c|}
\hline States & Districts & $\begin{array}{c}\text { Estimated } \\
\text { TFR }\end{array}$ & SE \\
\hline India & Total & 2.29 & 0.071 \\
\hline \multirow{4}{*}{$\begin{array}{c}\text { Andaman } \\
\text { and Nicobar } \\
\text { Islands }\end{array}$} & Nicobars & 1.44 & 0.116 \\
\hline & North \& Middle Andaman & 1.77 & 0.079 \\
\hline & South Andaman & 1.30 & 0.134 \\
\hline & Total & 1.51 & 0.107 \\
\hline \multirow{14}{*}{$\begin{array}{l}\text { Andhra } \\
\text { Pradesh }\end{array}$} & Srikakulam & 1.69 & 0.088 \\
\hline & Vizianagaram & 1.64 & 0.093 \\
\hline & Visakhapatnam & 1.65 & 0.091 \\
\hline & East Godavari & 1.58 & 0.099 \\
\hline & West Godavari & 1.65 & 0.091 \\
\hline & Krishna & 1.70 & 0.086 \\
\hline & Guntur & 1.43 & 0.117 \\
\hline & Prakasam & 1.96 & 0.067 \\
\hline & $\begin{array}{c}\text { Sri Potti Sriramulu } \\
\text { Nellore }\end{array}$ & 1.94 & 0.068 \\
\hline & Y.S.R. & 1.54 & 0.103 \\
\hline & Kurnool & 1.54 & 0.104 \\
\hline & Anantapur & 1.10 & 0.161 \\
\hline & Chittoor & 1.53 & 0.105 \\
\hline & Total & 1.62 & 0.095 \\
\hline \multirow{17}{*}{$\begin{array}{l}\text { Arunachal } \\
\text { Pradesh }\end{array}$} & Tawang & 1.78 & 0.079 \\
\hline & West Kameng & 1.71 & 0.085 \\
\hline & East Kameng & 2.16 & 0.065 \\
\hline & Papumpare & 1.87 & 0.072 \\
\hline & Upper Subansiri & 1.89 & 0.071 \\
\hline & West Siang & 1.64 & 0.092 \\
\hline & East Siang & 1.35 & 0.127 \\
\hline & Upper Siang & 1.74 & 0.083 \\
\hline & Changlang & 1.76 & 0.081 \\
\hline & Tirap & 1.95 & 0.068 \\
\hline & Lower Subansiri & 1.80 & 0.077 \\
\hline & Kurung Kumey & 1.97 & 0.067 \\
\hline & Dibang Valley & 1.70 & 0.087 \\
\hline & Lower Dibang Valley & 1.76 & 0.081 \\
\hline & Lohit & 2.28 & 0.071 \\
\hline & Anjaw & 1.53 & 0.105 \\
\hline & Total & 1.87 & 0.072 \\
\hline \multirow{27}{*}{ Assam } & Kokrajhar & 2.04 & 0.065 \\
\hline & Dhubri & 2.10 & 0.064 \\
\hline & Goalpara & 2.17 & 0.066 \\
\hline & Barpeta & 2.53 & 0.093 \\
\hline & Morigaon & 2.53 & 0.093 \\
\hline & Nagaon & 2.43 & 0.083 \\
\hline & Sonitpur & 1.93 & 0.068 \\
\hline & Lakhimpur & 1.92 & 0.069 \\
\hline & Dhemaji & 2.08 & 0.064 \\
\hline & Tinsukia & 2.10 & 0.064 \\
\hline & Dibrugarh & 1.82 & 0.075 \\
\hline & Sivasagar & 1.55 & 0.103 \\
\hline & Jorhat & 2.12 & 0.065 \\
\hline & Golaghat & 1.91 & 0.070 \\
\hline & Karbi Anglong & 1.61 & 0.095 \\
\hline & Dima Hasao & 1.65 & 0.091 \\
\hline & Cachar & 2.21 & 0.067 \\
\hline & Karimganj & 2.32 & 0.073 \\
\hline & Hailakandi & 2.65 & 0.107 \\
\hline & Bongaigaon & 2.00 & 0.066 \\
\hline & Chirang & 1.72 & 0.084 \\
\hline & Kamrup & 1.65 & 0.092 \\
\hline & Kamrup Metropolitan & 1.31 & 0.133 \\
\hline & Nalbari & 2.04 & 0.065 \\
\hline & Baksa & 1.49 & 0.110 \\
\hline & Darrang & 2.89 & 0.137 \\
\hline & Udalguri & 2.01 & 0.065 \\
\hline
\end{tabular}




\begin{tabular}{|c|c|c|c|}
\hline & Total & 2.04 & 0.065 \\
\hline \multirow{39}{*}{ Bihar } & Pashchim Champaran & 2.05 & 0.065 \\
\hline & Purba Champaran & 2.53 & 0.093 \\
\hline & Sheohar & 3.03 & 0.156 \\
\hline & Sitamarhi & 3.03 & 0.156 \\
\hline & Madhubani & 2.12 & 0.065 \\
\hline & Supaul & 2.54 & 0.094 \\
\hline & Araria & 2.57 & 0.098 \\
\hline & Kishanganj & 2.93 & 0.142 \\
\hline & Purnia & 2.63 & 0.104 \\
\hline & Katihar & 2.22 & 0.068 \\
\hline & Madhepura & 2.19 & 0.066 \\
\hline & Saharsa & 2.91 & 0.139 \\
\hline & Darbhanga & 2.59 & 0.100 \\
\hline & Muzaffarpur & 3.07 & 0.162 \\
\hline & Gopalganj & 2.69 & 0.112 \\
\hline & Siwan & 2.58 & 0.099 \\
\hline & Saran & 2.71 & 0.114 \\
\hline & Vaishali & 2.41 & 0.081 \\
\hline & Samastipur & 2.70 & 0.114 \\
\hline & Begusarai & 3.09 & 0.164 \\
\hline & Khagaria & 2.46 & 0.086 \\
\hline & Bhagalpur & 2.66 & 0.108 \\
\hline & Banka & 2.56 & 0.096 \\
\hline & Munger & 2.89 & 0.137 \\
\hline & Lakhisarai & 2.76 & 0.120 \\
\hline & Sheikhpura & 2.82 & 0.128 \\
\hline & Nalanda & 2.66 & 0.109 \\
\hline & Patna & 2.58 & 0.098 \\
\hline & Bhojpur & 3.27 & 0.190 \\
\hline & Buxar & 2.66 & 0.108 \\
\hline & Kaimur (Bhabua) & 2.67 & 0.109 \\
\hline & Rohtas & 2.96 & 0.147 \\
\hline & Aurangabad & 3.00 & 0.153 \\
\hline & Gaya & 3.17 & 0.176 \\
\hline & Nawada & 3.22 & 0.182 \\
\hline & Jamui & 2.78 & 0.123 \\
\hline & Jehanabad & 2.96 & 0.146 \\
\hline & Arwal & 3.06 & 0.160 \\
\hline & Total & 2.74 & 0.118 \\
\hline \multirow{2}{*}{ Chandigarh } & Chandigarh & 1.80 & 0.077 \\
\hline & Total & 1.80 & $\mathbf{0 . 0 7 7}$ \\
\hline \multirow{19}{*}{ Chhattisgarh } & Korea (Koriya) & 2.26 & 0.070 \\
\hline & Surguja & 2.29 & 0.071 \\
\hline & Jashpur & 1.89 & 0.071 \\
\hline & Raigarh & 2.42 & 0.082 \\
\hline & Korba & 2.58 & 0.098 \\
\hline & Janjgir - Champa & 3.29 & 0.193 \\
\hline & Bilaspur & 2.79 & 0.124 \\
\hline & Kabirdham & 3.19 & 0.178 \\
\hline & Rajnandgaon & 2.70 & 0.113 \\
\hline & Durg & 2.48 & 0.088 \\
\hline & Raipur & 2.51 & 0.090 \\
\hline & Mahasamund & 2.84 & 0.131 \\
\hline & Dhamtari & 2.78 & 0.123 \\
\hline & Uttar Bastar Kanker & 2.55 & 0.095 \\
\hline & Bastar & 2.05 & 0.065 \\
\hline & Narayanpur & 2.49 & 0.089 \\
\hline & $\begin{array}{c}\text { Dakshin Bastar } \\
\text { Dantewada }\end{array}$ & 2.06 & 0.064 \\
\hline & Bijapur & 2.63 & 0.105 \\
\hline & Total & 2.56 & 0.096 \\
\hline \multirow{2}{*}{$\begin{array}{c}\text { Dadra and } \\
\text { Nagar Haveli }\end{array}$} & Dadra \& Nagar Haveli & 1.83 & 0.075 \\
\hline & Total & 1.83 & 0.075 \\
\hline \multirow{3}{*}{$\begin{array}{c}\text { Daman and } \\
\text { Diu }\end{array}$} & Diu & 2.28 & 0.071 \\
\hline & Daman & 1.08 & 0.164 \\
\hline & Total & 1.78 & 0.079 \\
\hline \multirow{3}{*}{ Goa } & North Goa & 1.36 & 0.126 \\
\hline & South Goa & 1.72 & 0.084 \\
\hline & Total & 1.53 & 0.105 \\
\hline Gujarat & Kachchh & 2.21 & 0.067 \\
\hline
\end{tabular}




\begin{tabular}{|c|c|c|c|}
\hline & Banaskantha & 2.77 & 0.121 \\
\hline & Patan & 1.94 & 0.068 \\
\hline & Mahesana & 2.10 & 0.064 \\
\hline & Sabarkantha & 2.46 & 0.086 \\
\hline & Gandhinagar & 1.60 & 0.097 \\
\hline & Ahmadabad & 1.68 & 0.088 \\
\hline & Surendranagar & 2.11 & 0.065 \\
\hline & Rajkot & 1.49 & 0.110 \\
\hline & Jamnagar & 1.61 & 0.096 \\
\hline & Porbandar & 1.83 & 0.075 \\
\hline & Junagadh & 1.98 & 0.066 \\
\hline & Amreli & 2.04 & 0.065 \\
\hline & Bhavnagar & 2.16 & 0.065 \\
\hline & Anand & 1.96 & 0.067 \\
\hline & Kheda & 2.21 & 0.067 \\
\hline & Panchmahal & 2.06 & 0.065 \\
\hline & Dohad & 2.46 & 0.086 \\
\hline & Vadodara & 2.04 & 0.065 \\
\hline & Narmada & 2.26 & 0.070 \\
\hline & Bharuch & 1.93 & 0.068 \\
\hline & The Dangs & 2.29 & 0.072 \\
\hline & Navsari & 1.55 & 0.102 \\
\hline & Valsad & 1.72 & 0.084 \\
\hline & Surat & 1.46 & 0.113 \\
\hline & Tapi & 2.03 & 0.065 \\
\hline & Total & 2.02 & 0.065 \\
\hline & Panchkula & 1.44 & 0.116 \\
\hline & Ambala & 1.88 & 0.071 \\
\hline & Yamunanagar & 1.87 & 0.072 \\
\hline & Kurukshetra & 1.74 & 0.083 \\
\hline & Kaithal & 1.94 & 0.068 \\
\hline & Karnal & 1.71 & 0.085 \\
\hline & Panipat & 1.40 & 0.121 \\
\hline & Sonipat & 1.92 & 0.069 \\
\hline & Jind & 2.00 & 0.066 \\
\hline & Fatehabad & 1.94 & 0.068 \\
\hline Harvana & Sirsa & 1.81 & 0.077 \\
\hline Haryana & Hisar & 2.44 & 0.084 \\
\hline & Bhiwani & 2.47 & 0.087 \\
\hline & Rohtak & 2.08 & 0.064 \\
\hline & Jhajjar & 1.55 & 0.103 \\
\hline & Mahendragarh & 2.58 & 0.099 \\
\hline & Rewari & 1.88 & 0.071 \\
\hline & Gurgaon & 1.17 & 0.152 \\
\hline & Mewat & 3.03 & 0.156 \\
\hline & Faridabad & 2.37 & 0.077 \\
\hline & Palwal & 2.43 & 0.083 \\
\hline & Total & 2.02 & 0.065 \\
\hline & Chamba & 2.06 & 0.065 \\
\hline & Kangra & 0.99 & 0.176 \\
\hline & Lahul and Spiti & 0.65 & 0.225 \\
\hline & Kullu & 1.66 & 0.090 \\
\hline & Mandi & 1.14 & 0.155 \\
\hline & Hamirpur & 1.57 & 0.100 \\
\hline $\begin{array}{l}\text { Himachal } \\
\text { Pradesh }\end{array}$ & Una & 1.62 & 0.095 \\
\hline & Bilaspur & 1.16 & 0.153 \\
\hline & Solan & 1.26 & 0.140 \\
\hline & Sirmaur & 1.90 & 0.070 \\
\hline & Shimla & 1.21 & 0.146 \\
\hline & Kinnaur & 1.52 & 0.106 \\
\hline & Total & 1.46 & 0.114 \\
\hline & Kupwara & 2.10 & 0.064 \\
\hline & Badgam & 1.99 & 0.066 \\
\hline & Leh & 0.67 & 0.222 \\
\hline & Kargil & 1.91 & 0.069 \\
\hline Jammu and & Punch & 2.97 & 0.149 \\
\hline Kashmir & Rajouri & 2.38 & 0.078 \\
\hline & Kathua & 2.17 & 0.066 \\
\hline & Baramula & 1.96 & 0.067 \\
\hline & Bandipore & 2.19 & 0.066 \\
\hline & Srinagar & 1.08 & 0.164 \\
\hline
\end{tabular}




\begin{tabular}{|c|c|c|c|}
\hline & Ganderbal & 1.78 & 0.079 \\
\hline & Pulwama & 1.24 & 0.142 \\
\hline & Shupiyan & 1.96 & 0.067 \\
\hline & Anantnag & 1.70 & 0.086 \\
\hline & Kulgam & 2.47 & 0.087 \\
\hline & Doda & 2.45 & 0.085 \\
\hline & Ramban & 2.29 & 0.071 \\
\hline & Kishtwar & 2.16 & 0.065 \\
\hline & Udhampur & 2.21 & 0.067 \\
\hline & Reasi & 2.38 & 0.078 \\
\hline & Jammu & 1.53 & 0.105 \\
\hline & Samba & 1.31 & 0.132 \\
\hline & Total & 2.03 & 0.065 \\
\hline \multirow{25}{*}{ Jharkhand } & Garhwa & 2.88 & 0.136 \\
\hline & Chatra & 2.20 & 0.067 \\
\hline & Kodarma & 2.47 & 0.087 \\
\hline & Giridih & 2.57 & 0.098 \\
\hline & Deoghar & 1.74 & 0.083 \\
\hline & Godda & 2.06 & 0.065 \\
\hline & Sahibganj & 2.26 & 0.070 \\
\hline & Pakur & 2.80 & 0.126 \\
\hline & Dhanbad & 2.38 & 0.079 \\
\hline & Bokaro & 2.68 & 0.110 \\
\hline & Lohardaga & 2.91 & 0.140 \\
\hline & Purbi Singhbhum & 1.69 & 0.087 \\
\hline & Palamu & 2.55 & 0.096 \\
\hline & Latehar & 2.53 & 0.093 \\
\hline & Hazaribagh & 2.69 & 0.112 \\
\hline & Ramgarh & 2.52 & 0.092 \\
\hline & Dumka & 1.91 & 0.069 \\
\hline & Jamtara & 2.41 & 0.081 \\
\hline & Ranchi & 2.46 & 0.086 \\
\hline & Khunti & 2.40 & 0.080 \\
\hline & Gumla & 2.88 & 0.136 \\
\hline & Simdega & 1.94 & 0.068 \\
\hline & Pashchimi Singhbhum & 2.30 & 0.072 \\
\hline & Saraikela Kharsawan & 2.42 & 0.082 \\
\hline & Total & 2.42 & 0.082 \\
\hline \multirow{31}{*}{ Karnataka } & Belgaum & 1.71 & 0.086 \\
\hline & Bagalkot & 2.30 & 0.072 \\
\hline & Bijapur & 1.39 & 0.122 \\
\hline & Bidar & 2.58 & 0.098 \\
\hline & Raichur & 1.76 & 0.081 \\
\hline & Koppal & 1.89 & 0.071 \\
\hline & Gadag & 2.18 & 0.066 \\
\hline & Dharwad & 1.67 & 0.089 \\
\hline & Uttara Kannada & 1.75 & 0.081 \\
\hline & Haveri & 1.68 & 0.088 \\
\hline & Bellary & 1.74 & 0.083 \\
\hline & Chitradurga & 1.92 & 0.069 \\
\hline & Davanagere & 1.87 & 0.072 \\
\hline & Shimoga & 1.44 & 0.115 \\
\hline & Udupi & 1.47 & 0.113 \\
\hline & Chikmagalur & 1.69 & 0.087 \\
\hline & Tumkur & 1.15 & 0.154 \\
\hline & Bangalore & 0.91 & 0.187 \\
\hline & Mandya & 1.58 & 0.099 \\
\hline & Hassan & 1.15 & 0.154 \\
\hline & Dakshina Kannada & 1.49 & 0.109 \\
\hline & Kodagu & 1.56 & 0.101 \\
\hline & Mysore & 1.48 & 0.112 \\
\hline & Chamarajanagar & 1.63 & 0.094 \\
\hline & Gulbarga & 1.87 & 0.072 \\
\hline & Yadgir & 2.27 & 0.071 \\
\hline & Kolar & 1.90 & 0.070 \\
\hline & Chikkaballapura & 1.65 & 0.092 \\
\hline & Bangalore Rural & 1.75 & 0.082 \\
\hline & Ramanagara & 1.50 & 0.108 \\
\hline & Total & 1.76 & 0.081 \\
\hline \multirow{2}{*}{ Kerala } & Kasaragod & 1.34 & 0.129 \\
\hline & Kannur & 1.43 & 0.118 \\
\hline
\end{tabular}




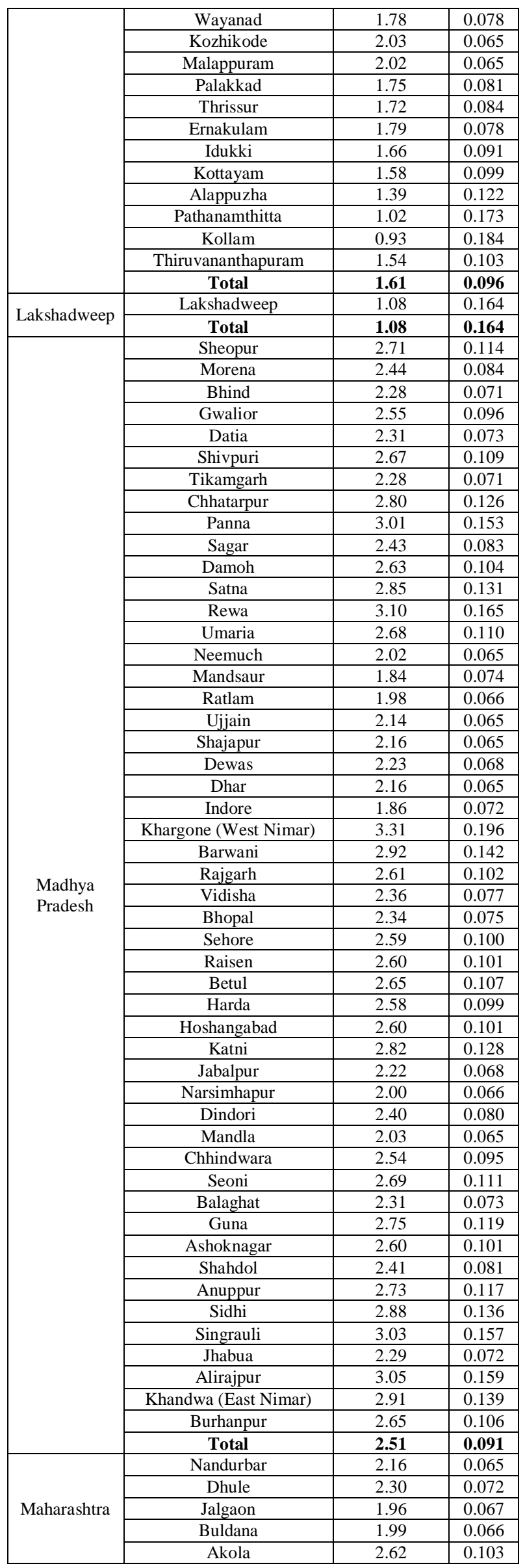




\begin{tabular}{|c|c|c|c|}
\hline & Washim & 1.97 & 0.066 \\
\hline & Amravati & 1.95 & 0.067 \\
\hline & Wardha & 1.73 & 0.083 \\
\hline & Nagpur & 1.77 & 0.080 \\
\hline & Bhandara & 1.99 & 0.066 \\
\hline & Gondiya & 1.58 & 0.099 \\
\hline & Gadchiroli & 2.20 & 0.067 \\
\hline & Chandrapur & 1.61 & 0.095 \\
\hline & Yavatmal & 1.88 & 0.071 \\
\hline & Nanded & 1.82 & 0.076 \\
\hline & Hingoli & 2.09 & 0.064 \\
\hline & Parbhani & 1.93 & 0.068 \\
\hline & Jalna & 2.13 & 0.065 \\
\hline & Aurangabad & 1.79 & 0.078 \\
\hline & Nashik & 2.11 & 0.065 \\
\hline & Thane & 2.08 & 0.064 \\
\hline & Mumbai Suburban & 2.02 & 0.065 \\
\hline & Mumbai & 2.11 & 0.065 \\
\hline & Raigarh & 1.73 & 0.084 \\
\hline & Pune & 1.53 & 0.105 \\
\hline & Ahmadnagar & 1.44 & 0.116 \\
\hline & Bid & 1.93 & 0.068 \\
\hline & Latur & 2.44 & 0.084 \\
\hline & Osmanabad & 2.08 & 0.064 \\
\hline & Solapur & 1.99 & 0.066 \\
\hline & Satara & 1.96 & 0.067 \\
\hline & Ratnagiri & 1.73 & 0.083 \\
\hline & Sindhudurg & 1.70 & 0.086 \\
\hline & Kolhapur & 1.52 & 0.106 \\
\hline & Sangli & 1.55 & 0.103 \\
\hline & Total & 1.97 & 0.067 \\
\hline & Senapati & 2.15 & 0.065 \\
\hline & Tamenglong & 1.62 & 0.095 \\
\hline & Churachandpur & 1.99 & 0.066 \\
\hline & Bishnupur & 1.76 & 0.080 \\
\hline Maninur & Thoubal & 2.11 & 0.065 \\
\hline Vianıpur & Imphal West & 1.32 & 0.132 \\
\hline & Imphal East & 1.43 & 0.117 \\
\hline & Ukhrul & 1.99 & 0.066 \\
\hline & Chandel & 1.69 & 0.087 \\
\hline & Total & 1.75 & 0.081 \\
\hline & West Garo Hills & 2.41 & 0.081 \\
\hline & East Garo Hills & 2.65 & 0.107 \\
\hline & South Garo Hills & 3.18 & 0.177 \\
\hline Merboy & West Khasi Hills & 2.63 & 0.105 \\
\hline Megnalaya & Ribhoi & 2.69 & 0.112 \\
\hline & East Khasi Hills & 2.14 & 0.065 \\
\hline & Jaintia Hills & 2.57 & 0.097 \\
\hline & Total & 2.58 & 0.098 \\
\hline & Mamit & 1.68 & 0.089 \\
\hline & Kolasib & 1.43 & 0.117 \\
\hline & Aizawl & 1.89 & 0.071 \\
\hline & Champhai & 1.78 & 0.078 \\
\hline Mizoram & Serchhip & 1.23 & 0.144 \\
\hline & Lunglei & 1.58 & 0.099 \\
\hline & Lawngtlai & 1.94 & 0.068 \\
\hline & Saiha & 2.07 & 0.064 \\
\hline & Total & 1.70 & 0.087 \\
\hline & Mon & 2.15 & 0.065 \\
\hline & Mokokchung & 1.10 & 0.161 \\
\hline & Zunheboto & 2.50 & 0.090 \\
\hline & Wokha & 1.49 & 0.110 \\
\hline & Dimapur & 1.81 & 0.076 \\
\hline Nagaland & Phek & 1.99 & 0.066 \\
\hline Nagaland & Tuensang & 1.47 & 0.113 \\
\hline & Longleng & 1.59 & 0.098 \\
\hline & Kiphire & 2.09 & 0.064 \\
\hline & Kohima & 1.70 & 0.087 \\
\hline & Peren & 1.87 & 0.072 \\
\hline & Total & 1.87 & 0.072 \\
\hline Delhi & North West & 1.79 & 0.078 \\
\hline
\end{tabular}




\begin{tabular}{|c|c|c|c|}
\hline & North & 2.00 & 0.066 \\
\hline & North East & 2.12 & 0.065 \\
\hline & East & 1.54 & 0.104 \\
\hline & New Delhi & 2.47 & 0.087 \\
\hline & Central & 1.92 & 0.069 \\
\hline & West & 1.67 & 0.089 \\
\hline & South West & 1.73 & 0.083 \\
\hline & South & 2.11 & 0.065 \\
\hline & Total & 1.93 & 0.068 \\
\hline \multirow{31}{*}{ Odisha } & Bargarh & 1.98 & 0.066 \\
\hline & Jharsuguda & 2.14 & 0.065 \\
\hline & Sambalpur & 1.80 & 0.077 \\
\hline & Debagarh & 1.52 & 0.107 \\
\hline & Sundargarh & 2.40 & 0.080 \\
\hline & Kendujhar & 2.10 & 0.064 \\
\hline & Mayurbhanj & 2.08 & 0.064 \\
\hline & Baleshwar & 2.02 & 0.065 \\
\hline & Bhadrak & 1.88 & 0.072 \\
\hline & Kendrapara & 1.90 & 0.070 \\
\hline & Jagatsinghapur & 2.15 & 0.065 \\
\hline & Cuttack & 1.40 & 0.121 \\
\hline & Jajapur & 2.07 & 0.064 \\
\hline & Dhenkanal & 1.79 & 0.078 \\
\hline & Anugul & 2.02 & 0.065 \\
\hline & Nayagarh & 1.91 & 0.069 \\
\hline & Khordha & 1.88 & 0.071 \\
\hline & Puri & 2.00 & 0.066 \\
\hline & Ganjam & 2.32 & 0.073 \\
\hline & Gajapati & 2.23 & 0.068 \\
\hline & Kandhamal & 2.98 & 0.150 \\
\hline & Baudh & 2.78 & 0.123 \\
\hline & Subarnapur & 2.02 & 0.065 \\
\hline & Balangir & 2.56 & 0.096 \\
\hline & Nuapada & 2.80 & 0.126 \\
\hline & Kalahandi & 2.31 & 0.073 \\
\hline & Rayagada & 2.79 & 0.124 \\
\hline & Nabarangapur & 2.82 & 0.128 \\
\hline & Koraput & 2.65 & 0.107 \\
\hline & Malkangiri & 2.17 & 0.066 \\
\hline & Total & 2.21 & 0.067 \\
\hline \multirow{5}{*}{ Puducherry } & Yanam & 1.77 & 0.080 \\
\hline & Puducherry & 1.80 & 0.077 \\
\hline & Mahe & 1.15 & 0.153 \\
\hline & Karaikal & 1.85 & 0.073 \\
\hline & Total & 1.71 & 0.086 \\
\hline \multirow{21}{*}{ Punjab } & Gurdaspur & 1.45 & 0.115 \\
\hline & Kapurthala & 2.22 & 0.068 \\
\hline & Jalandhar & 1.51 & 0.108 \\
\hline & Hoshiarpur & 1.65 & 0.091 \\
\hline & Sangrur & 1.41 & 0.120 \\
\hline & Fatehgarh Sahib & 1.49 & 0.109 \\
\hline & Ludhiana & 1.46 & 0.113 \\
\hline & Moga & 1.89 & 0.070 \\
\hline & Firozpur & 1.76 & 0.080 \\
\hline & Muktsar & 1.06 & 0.167 \\
\hline & Faridkot & 1.53 & 0.105 \\
\hline & Bathinda & 1.73 & 0.083 \\
\hline & Mansa & 1.77 & 0.080 \\
\hline & Patiala & 1.33 & 0.129 \\
\hline & Amritsar & 1.91 & 0.069 \\
\hline & Tarn Taran & 1.56 & 0.102 \\
\hline & Rupnagar & 1.39 & 0.123 \\
\hline & SAS Nagar & 1.05 & 0.168 \\
\hline & SBS Nagar & 1.75 & 0.081 \\
\hline & Barnala & 1.79 & 0.078 \\
\hline & Total & 1.60 & 0.097 \\
\hline \multirow{5}{*}{ Rajasthan } & Ganganagar & 2.33 & 0.074 \\
\hline & Hanumangarh & 1.87 & 0.072 \\
\hline & Bikaner & 2.53 & 0.094 \\
\hline & Churu & 2.52 & 0.092 \\
\hline & Jhunjhunun & 2.70 & 0.113 \\
\hline
\end{tabular}




\begin{tabular}{|c|c|c|c|}
\hline & Alwar & 2.19 & 0.066 \\
\hline & Bharatpur & 2.67 & 0.109 \\
\hline & Dhaulpur & 2.93 & 0.142 \\
\hline & Karauli & 3.45 & 0.216 \\
\hline & Sawai Madhopur & 2.78 & 0.123 \\
\hline & Dausa & 2.96 & 0.147 \\
\hline & Jaipur & 2.18 & 0.066 \\
\hline & Sikar & 2.51 & 0.090 \\
\hline & Nagaur & 2.95 & 0.146 \\
\hline & Jodhpur & 2.38 & 0.078 \\
\hline & Jaisalmer & 1.82 & 0.075 \\
\hline & Barmer & 2.30 & 0.072 \\
\hline & Jalor & 2.55 & 0.095 \\
\hline & Sirohi & 2.29 & 0.071 \\
\hline & Pali & 2.99 & 0.150 \\
\hline & Ajmer & 2.35 & 0.076 \\
\hline & Tonk & 2.79 & 0.124 \\
\hline & Bundi & 2.61 & 0.102 \\
\hline & Bhilwara & 2.49 & 0.089 \\
\hline & Rajsamand & 2.46 & 0.086 \\
\hline & Dungarpur & 2.66 & 0.108 \\
\hline & Banswara & 2.33 & 0.074 \\
\hline & Chittaurgarh & 1.69 & 0.087 \\
\hline & Kota & 2.04 & 0.065 \\
\hline & Baran & 2.77 & 0.122 \\
\hline & Jhalawar & 2.24 & 0.069 \\
\hline & Udaipur & 2.47 & 0.087 \\
\hline & Pratapgarh & 2.37 & 0.078 \\
\hline & Total & 2.48 & 0.088 \\
\hline & North District & 1.89 & 0.071 \\
\hline & West District & 2.03 & 0.065 \\
\hline Sikkim & South District & 1.98 & 0.066 \\
\hline & East District & 1.13 & 0.156 \\
\hline & Total & 1.65 & 0.091 \\
\hline & Thiruvallur & 2.19 & 0.066 \\
\hline & Chennai & 1.19 & 0.148 \\
\hline & Kancheepuram & 1.46 & 0.113 \\
\hline & Vellore & 1.59 & 0.099 \\
\hline & Tiruvannamalai & 1.71 & 0.085 \\
\hline & Viluppuram & 1.66 & 0.090 \\
\hline & Salem & 2.50 & 0.090 \\
\hline & Namakkal & 1.65 & 0.092 \\
\hline & Erode & 2.46 & 0.086 \\
\hline & The Nilgiris & 1.89 & 0.071 \\
\hline & Dindigul & 1.68 & 0.088 \\
\hline & Karur & 1.56 & 0.101 \\
\hline & Tiruchirappalli & 1.45 & 0.115 \\
\hline & Perambalur & 2.07 & 0.064 \\
\hline & Ariyalur & 1.15 & 0.154 \\
\hline & Cuddalore & 1.63 & 0.094 \\
\hline Tamil Nadu & Nagapattinam & 1.76 & 0.080 \\
\hline & Thiruvarur & 0.95 & 0.181 \\
\hline & Thanjavur & 1.90 & 0.070 \\
\hline & Pudukkottai & 1.17 & 0.152 \\
\hline & Sivaganga & 1.45 & 0.115 \\
\hline & Madurai & 0.99 & 0.176 \\
\hline & Theni & 1.57 & 0.100 \\
\hline & Virudhunagar & 1.51 & 0.108 \\
\hline & Ramanathapuram & 1.61 & 0.096 \\
\hline & Thoothukkudi & 1.38 & 0.123 \\
\hline & Tirunelveli & 1.55 & 0.102 \\
\hline & Kanniyakumari & 1.11 & 0.160 \\
\hline & Dharmapuri & 2.30 & 0.072 \\
\hline & Krishnagiri & 2.23 & 0.068 \\
\hline & Coimbatore & 2.02 & 0.065 \\
\hline & Tiruppur & 1.79 & 0.078 \\
\hline & Total & 1.69 & 0.088 \\
\hline & West Tripura & 1.61 & 0.096 \\
\hline & South Tripura & 1.95 & 0.067 \\
\hline I ripura & Dhalai & 1.95 & 0.067 \\
\hline & North Tripura & 2.18 & 0.066 \\
\hline
\end{tabular}




\begin{tabular}{|c|c|c|c|}
\hline & Total & 1.86 & 0.072 \\
\hline \multirow{70}{*}{ Uttar Pradesh } & Saharanpur & 2.69 & 0.112 \\
\hline & Muzaffarnagar & 2.74 & 0.118 \\
\hline & Bijnor & 3.09 & 0.165 \\
\hline & Moradabad & 3.20 & 0.180 \\
\hline & Rampur & 3.19 & 0.179 \\
\hline & Jyotiba Phule Nagar & 3.24 & 0.186 \\
\hline & Meerut & 2.72 & 0.115 \\
\hline & Baghpat & 2.92 & 0.141 \\
\hline & Ghaziabad & 2.64 & 0.105 \\
\hline & Gautam Buddha Nagar & 2.06 & 0.065 \\
\hline & Bulandshahr & 2.94 & 0.144 \\
\hline & Aligarh & 2.90 & 0.139 \\
\hline & Mahamaya Nagar & 2.84 & 0.131 \\
\hline & Mathura & 3.22 & 0.182 \\
\hline & Agra & 2.92 & 0.141 \\
\hline & Firozabad & 3.26 & 0.188 \\
\hline & Mainpuri & 3.23 & 0.183 \\
\hline & Budaun & 3.12 & 0.169 \\
\hline & Bareilly & 3.34 & 0.200 \\
\hline & Pilibhit & 2.95 & 0.146 \\
\hline & Shahjahanpur & 2.99 & 0.151 \\
\hline & Kheri & 2.62 & 0.103 \\
\hline & Sitapur & 2.62 & 0.104 \\
\hline & Hardoi & 2.81 & 0.126 \\
\hline & Unnao & 3.14 & 0.172 \\
\hline & Lucknow & 2.33 & 0.075 \\
\hline & Rae Bareli & 3.43 & 0.212 \\
\hline & Farrukhabad & 2.90 & 0.138 \\
\hline & Kannauj & 2.94 & 0.144 \\
\hline & Etawah & 2.87 & 0.135 \\
\hline & Auraiya & 2.38 & 0.079 \\
\hline & Kanpur Dehat & 2.53 & 0.093 \\
\hline & Kanpur Nagar & 2.32 & 0.074 \\
\hline & Jalaun & 2.56 & 0.096 \\
\hline & Jhansi & 2.67 & 0.110 \\
\hline & Lalitpur & 2.40 & 0.081 \\
\hline & Hamirpur & 2.93 & 0.143 \\
\hline & Mahoba & 3.29 & 0.192 \\
\hline & Banda & 2.89 & 0.138 \\
\hline & Chitrakoot & 3.38 & 0.205 \\
\hline & Fatehpur & 2.90 & 0.138 \\
\hline & Pratapgarh & 3.15 & 0.173 \\
\hline & Kaushambi & 3.37 & 0.204 \\
\hline & Allahabad & 2.78 & 0.122 \\
\hline & Bara Banki & 2.76 & 0.120 \\
\hline & Faizabad & 3.25 & 0.187 \\
\hline & Ambedkar Nagar & 3.07 & 0.161 \\
\hline & Sultanpur & 3.42 & 0.211 \\
\hline & Bahraich & 2.22 & 0.067 \\
\hline & Shrawasti & 2.27 & 0.071 \\
\hline & Balrampur & 2.71 & 0.114 \\
\hline & Gonda & 2.96 & 0.146 \\
\hline & Siddharth Nagar & 3.08 & 0.163 \\
\hline & Basti & 3.12 & 0.168 \\
\hline & Sant Kabir Nagar & 3.24 & 0.186 \\
\hline & Mahrajganj & 3.51 & 0.223 \\
\hline & Gorakhpur & 2.98 & 0.149 \\
\hline & Kushinagar & 3.37 & 0.204 \\
\hline & Deoria & 3.02 & 0.155 \\
\hline & Azamgarh & 3.19 & 0.178 \\
\hline & Mau & 3.30 & 0.194 \\
\hline & Ballia & 3.23 & 0.183 \\
\hline & Jaunpur & 2.95 & 0.146 \\
\hline & Ghazipur & 3.22 & 0.182 \\
\hline & Chandauli & 2.89 & 0.137 \\
\hline & Varanasi & 2.60 & 0.101 \\
\hline & Bhadohi (SRN) & 2.87 & 0.134 \\
\hline & Mirzapur & 2.72 & 0.115 \\
\hline & Sonbhadra & 2.55 & 0.095 \\
\hline & Etah & 2.99 & 0.151 \\
\hline
\end{tabular}




\begin{tabular}{|c|c|c|c|}
\hline & Kanshiram Nagar & 3.19 & 0.178 \\
\hline & Total & 2.93 & 0.142 \\
\hline \multirow{14}{*}{ Uttarakhand } & Uttarkashi & 2.33 & 0.075 \\
\hline & Chamoli & 2.02 & 0.065 \\
\hline & Rudraprayag & 2.41 & 0.081 \\
\hline & Tehri Garhwal & 2.28 & 0.071 \\
\hline & Dehradun & 2.09 & 0.064 \\
\hline & Garhwal & 2.82 & 0.128 \\
\hline & Pithoragarh & 1.87 & 0.072 \\
\hline & Bageshwar & 2.48 & 0.088 \\
\hline & Almora & 2.69 & 0.111 \\
\hline & Champawat & 2.65 & 0.107 \\
\hline & Nainital & 2.29 & 0.072 \\
\hline & Udham Singh Nagar & 2.42 & 0.082 \\
\hline & Hardwar & 2.96 & 0.147 \\
\hline & Total & 2.46 & 0.085 \\
\hline \multirow{20}{*}{ West Bengal } & Darjiling & 2.14 & 0.065 \\
\hline & Jalpaiguri & 2.46 & 0.086 \\
\hline & Koch Bihar & 2.24 & 0.069 \\
\hline & Uttar Dinajpur & 3.19 & 0.179 \\
\hline & Dakshin Dinajpur & 2.74 & 0.118 \\
\hline & Maldah & 2.21 & 0.067 \\
\hline & Murshidabad & 2.21 & 0.067 \\
\hline & Birbhum & 2.34 & 0.075 \\
\hline & Barddhaman & 2.03 & 0.065 \\
\hline & Nadia & 2.02 & 0.065 \\
\hline & North 24 Parganas & 1.67 & 0.090 \\
\hline & Hugli & 1.78 & 0.079 \\
\hline & Bankura & 2.22 & 0.068 \\
\hline & Puruliya & 2.08 & 0.064 \\
\hline & Haora & 2.13 & 0.065 \\
\hline & Kolkata & 1.62 & 0.094 \\
\hline & South 24 Parganas & 2.71 & 0.114 \\
\hline & Paschim Medinipur & 2.65 & 0.107 \\
\hline & Purba Medinipur & 1.99 & 0.066 \\
\hline & Total & 2.27 & 0.070 \\
\hline \multirow{11}{*}{ Telangana } & Adilabad & 1.96 & 0.067 \\
\hline & Nizamabad & 1.67 & 0.089 \\
\hline & Karimnagar & 1.58 & 0.099 \\
\hline & Medak & 1.75 & 0.081 \\
\hline & Hyderabad & 1.67 & 0.090 \\
\hline & Rangareddy & 1.46 & 0.113 \\
\hline & Mahbubnagar & 1.53 & 0.105 \\
\hline & Nalgonda & 2.16 & 0.065 \\
\hline & Warangal & 1.64 & 0.093 \\
\hline & Khammam & 2.00 & 0.066 \\
\hline & Total & 1.75 & 0.082 \\
\hline
\end{tabular}

